\title{
Tildipirosinin Sığır Trakea Epitel Hücresi Üzerinde Yara İyileştirici Etkisi
}

\author{
Yaşar ŞAHIN ${ }^{1, a,{ }^{*}, \text { Ebru YILDIRIM }}{ }^{1, b}$, Hüsamettin EKici ${ }^{1, c}$, Mustafa TÜRK $^{2, d}$, \\ Esra ARAT ${ }^{3, e}$
}

\author{
${ }^{1}$ Kırıkkale Üniversitesi, Veteriner Fakültesi, Farmakoloji ve Toksikoloji Anabilim Dalı, Yahşihan, Kırıkkale, Türkiye \\ ${ }^{2}$ Kırıkkale Üniversitesi, Mühendislik ve Mimarlık Fakültesi, Biyomühendislik Anabilim Dalı, Yahşihan, Kırıkkale, Türkiye \\ ${ }^{3}$ Kırıkkale Üniversitesi, Bilimsel ve Teknolojik Araştırmalar Uygulama ve Araştırma Merkezi Müdürlüğü (KÜBTUAM), \\ Yahşihan, Kırıkkale, Türkiye \\ aORCID numarası: 0000-0001-5936-4210, b ORCID numarası: 0000-0002-6289-0729, 'ORCID numarası: 0000-0001-6403- \\ 737X, dORCID numarası: 0000-0001-8202-090X, e ORCID numarası: 0000-0002-9259-2538
}

\begin{abstract}
Özet: Bu çalışmada; sığır solunum yolu hastalıkları tedavisinde kullanılan tildipirosinin, sığır trakea epitel hücresi üzerinde in vitro yara iyileşmesi etkisinin araştırılması amaçlandı. In vitro yara yöntemi ile her kuyucuğa ekilmiş olan sığır trakea epitel hücreleri üzerinde, $200 \mu \mathrm{L}$ 'lik pipet ucu (dikey) aracılığıyla bir yara alanı oluşturuldu. In vitro yara oluşturulmuş sığır trakea epitel hücreleri üzerine tildipirosinin konsantrasyonları $(5 \mu \mathrm{g} / \mathrm{mL}, 10 \mu \mathrm{g} / \mathrm{mL}, 25 \mu \mathrm{g} / \mathrm{mL}, 50 \mu \mathrm{g} / \mathrm{mL}$ ) ve kontrol grubu

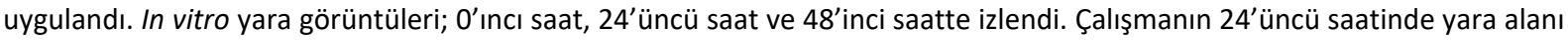
kapanma yüzdesi, kontrol grubuna kıyasla; tildipirosinin $50 \mu \mathrm{g} / \mathrm{mL}$ konsantrasyonda istatistiki olarak önemli fark bulunamazken 5, 10 ve $25 \mu \mathrm{g} / \mathrm{mL}$ konsantrasyonlarında istatistiki olarak fark anlamlı bulundu. Çalışmanın $48^{\prime}$ inci saatinde, kontrol grubuna kıyasla 25 ve $50 \mu \mathrm{g} / \mathrm{mL}$ tildipirosin konsantrasyonları arasında istatistiki olarak önemli fark bulunamazken, 5 $\mu \mathrm{g} / \mathrm{mL}(\% 96,61 \pm 1,69)$ ve $10 \mu \mathrm{g} / \mathrm{mL}(\% 96,42 \pm 1,78)$ tildipirosin konsantrasyonları arasında yara alanı kapanma yüzdeleri arasında istatistiki olarak fark anlamlı bulundu. Sonuç olarak tildipirosinin düşük konsantrasyonlarındaki yara iyileşme yüzdelerinin (48'inci saat) yaklaşık olarak \%96 olması, hastalıkların tedavisine ek olarak çeşitli mikroorganizma ve maddeler tarafından epitel hücrelerinde meydana gelen hasarlara karşı doku bütünlüğünü koruma ve tedaviye katkı sağlayabilir.

Anahtar Kelimeler: In vitro, Sı̆̆ır, Tildipirosin, Trakea epitel hücresi, Yara iyileşmesi
\end{abstract}

\section{Wound Healing Effect of Tildipirosin on Bovine Tracheal Epithelial Cell}

\begin{abstract}
This study aimed to investigate the in vitro wound healing effect of tildipirosin, used in treating bovine respiratory diseases, on bovine tracheal epithelial cells. With an in vitro wound method, a wounded area was created on bovine tracheal epithelial cells found in each well with a $200 \mu \mathrm{L}$ pipette tip (vertical). Concentrations of tildipirosin $(5 \mu \mathrm{g} / \mathrm{mL}, 10$ $\mu \mathrm{g} / \mathrm{mL}, 25 \mu \mathrm{g} / \mathrm{mL}, 50 \mu \mathrm{g} / \mathrm{mL}$ ) and control group were applied on in vitro wound formed bovine tracheal epithelial cells. In vitro wound images were monitored at 0 th, 24 th and 48 th hours. No statistically significant difference was found at 50 $\mu \mathrm{g} / \mathrm{mL}$ concentration of tildipirosin at the 24 th hour of the study regarding to wound healing area. In contrast, the difference was statistically significant at 5,10 , and $25 \mu \mathrm{g} / \mathrm{mL}$ concentrations of tildipirosin as compared to control group. At the 48th hour of the study, there was no statistically significant difference between 25 and $50 \mu \mathrm{g} / \mathrm{mL}$ concentrations of tildipirosin compared to the control group. In contrast, $5 \mu \mathrm{g} / \mathrm{mL}(\% 96,61 \pm 1,69)$ and $10 \mu \mathrm{g} / \mathrm{mL}(\% 96,42 \pm 1,78)$ tildipirosin statistically increased the wound healing percentage. To conclude, the wound healing rate (48th hour) at low concentrations of tildipirosin was approximately \%96, and this may contribute to the protection and treatment of tissue integrity against epithelial cell damage by various microorganisms and substances in addition to the treatment of diseases. Keywords: Bovine, In vitro, Tildipirosin, Tracheal epithelial cell, Wound healing.
\end{abstract}

\section{Giriş}

Tildipirosin; sığır solunum yolu hastalığına neden olan Mannheimia haemolytica ve Pasteurella multocida gibi bakteriyel patojenlerin tedavisi için geliştirilmiş makrolid grubu bir antibiyotiktir (Anderson ve ark., 2012; Peres ve ark., 2020). Son yıllarda sığır ve domuz solunum yolu hastalığı tedavisi için ruhsatlandırılmış olan tildipirosin, 16 üyeli halkalılar sınıfında yer almakta olup (Lei ve ark., 2018; Zeng ve ark., 2018), doğal olarak oluşan tilosinden türetilen yarı sentetik bir makroliddir (Giguère, 2013). Diğer makrolid grubu antibiyotikler gibi tildipirosin, bakteri ribozomunun $50 \mathrm{~S}$ alt birimine bağlanıp protein sentezini engeller ve bakteriyostatik etki yapmaktadır (Papich, 2018; Pyörälä ve ark., 2014; Zhanel ve ark., 2001).

Genel olarak makrolid antibiyotikler; dokulara geniş dağılım göstermesinden ve periferal dokulardaki yoğunluğu serumdaki yoğunluğundan yüksek olmasından dolayı akciğerdeki yoğunlukları uzun sürelidir (Benchaoui ve ark., 2004; Nowakowski ve ark., 2004). Tildipirosin, solunum sistemine hızlı ve geniş bir şekilde dağılır ve yavaş 
bir şekilde elimine edilmektedir (Menge ve ark., 2012; Zeng ve ark., 2018). Tildipirosinin yapısındaki bazik azot grupları, pKa değerleri altındaki asidik ortamlarda pozitif yüklenmesine neden olabilmektedir. Bu özelliğiyle; hücre içi ilgisi artarak, hücre içi geniş dağılım göstermesine neden olmaktadır (Papich, 2018). Dağılım hacminin yüksek olması ve hücre içinde önemli oranda bulunmasından dolayı hücre içi bakteriler üzerinde geniş etki göstermesi beklenmektedir (Galecio ve ark., 2020). Makrolid antibiyotiklerin; nötrofil, makrofaj ve solunum yolu epitel hücreleri gibi çok sayıda ökaryot hücrede birikebilmekle birlikte (Čulić ve ark., 2001), hücre içi yoğunluğu hücre dışı yoğunluğundan yaklaşık 300 kat fazla olabilmektedir (Van Bambeke ve ark., 2006). Ancak hücre içi bakteriler tarafından meydana gelen hastalıkların tedavisinde sadece ilacın hücre yoğunluğunun yüksek olması yeterli olmayabilir. Ayrıca ilacın hücre içinde yeterli süre ve konsantrasyonda bulunması da gerekmektedir (Şahin ve Yıldırım, 2020).

Makrolid antibiyotiklerin antimikrobiyel etkisinin yanında antiinflamatuar ve immünomodülatör etkilerinin olduğu bilinmektedir (Fischer ve ark., 2011; Guillot ve ark., 2011; lanaro ve ark., 2000). Bu antibiyotiklerin antiinflamatuar etkisi, proinflamatuar aracılar ve sitokinlerin üretimini önleme yeteneğine bağlıdır. Bu özelliklerinden dolayı antibakteriyel etkilerinden bağımsız olarak terapötik etkiler gösterebileceği öne sürülmüştür (lanaro ve ark., 2000). Yapılan literatür taramasında tildipirosinin sığır trakea epitel hücresi üzerinde in vitro yara iyileşmesi etkisini araştıran bir çalışma bulunamamıştır. Bu nedenle yapılan çalışmada, tildipirosinin sığır trakea epitel hücresi üzerinde in vitro yara iyileşmesi etkisinin araştırılması amaçlanmıştır.

\section{Materyal ve Metot}

Kırıkkale Üniversitesi Hayvan Deneyleri Yerel Etik Kurulu'ndan etik kurul onayı gerekmediği yazısı alındı (Evrak tarih ve sayısı: 21/02/2020-E.1538).

Tildipirosinin (BLDPharn, BD448267, Çin) konsantrasyonları, \%0,1 dimetil sülfoksit (DMSO, İsolab, Almanya) ve \%99,9 besiyerinde çözdürülerek hazırlandı.

Hücre Kültürü İzolasyonu: Sığır trakea epitel doku örnekleri, mezbahanede kesilen sağlıklı Simental ırkı erkek sığırlardan alındı. Bu trakea epitel doku örnekleri, önce $\% 0,9$ izotonik ile seyreltilmiş \%1-2 batikon solüsyonuna ve sonra $\% 0,9$ izotonik içine batırılıp çıkarıldı. Trakea epitel doku örnekleri, antibiyotikli PBS ile yıkandıktan sonra bağ dokusu parçalarından arındırılarak petri kutularına yerleştirildi. Dokudan; hücrelerini izole etmek için, önce örnekler mekanik olarak kazındı ve sonra küçük parçalara bölündü. Elde edilen bu doku örnekleri; besiyeri (\%79 DMEM-F2, \%20 fötal sığır serumu, \%1 penisilin-streptomisin) bulunan 25 $\mathrm{cm}^{2}$ lik kültür flasklarına koyularak inkübe (\%5 $\mathrm{CO}^{2} /$ hava, $37^{\circ} \mathrm{C}$ ) edildi. Sığır trakea epitel hücrelerinin çoğalmasına bağlı olarak besiyeri (\%89 DMEM-F2, \%10 fötal sığır serumu, \%1 penisilinstreptomisin) yaklaşık iki günde bir değiştirildi (Beckmann ve ark., 1991; Kürüm ve ark., 2019).

In Vitro Yara Modeli: Sığır trakea epitel hücreleri; hemositometri cihazı ile sayımı yapıldıktan sonra, her kuyucukta $3 \times 10^{4}$ hücre olacak şekilde 24 kuyucuklu plate'e ekildi. Hücreler, etüvde (\%5 $\mathrm{CO}_{2} /$ hava, $37^{\circ} \mathrm{C}$ ) 24 saat inkübe edildi. Bu inkübasyon sonunda, trakea epitel hücrelerinin bulunduğu 24 kuyucuklu plateden hücre vasatları çıkartıldı. Her kuyucuk tabanında, $200 \mu L^{\prime}$ lik pipet ucu (dikey) aracılıyla bir yara alanı oluşturuldu. Bu çizme işlemi sonucu plateden ayrılan hücreler, PBS ile yıkanarak uzaklaştırıldı. Önceden hazırlanmış olan etken madde konsantrasyonları $(5 \mu \mathrm{g} / \mathrm{mL}, 10$ $\mu \mathrm{g} / \mathrm{mL}, 25 \mu \mathrm{g} / \mathrm{mL}, 50 \mu \mathrm{g} / \mathrm{mL}$ ) ve kontrol grubu (\%0,1 DMSO-\%99,9 besiyeri) üç tekrarlı olacak şekilde trakea epitel hücreleri üzerine uygulandı. In vitro yara görüntüleri; $0^{\prime} ı n c ı$ saat, 24 'üncü saat ve $48^{\prime}$ inci saatte Leica DM6000 inverted mikroskop aracilıyla izlendi ve görüntüler alındı (Wang ve ark., 2019).

İstatistiksel Değerlendirme: In vitro yara görüntüleri; model oluşturulduktan 0,24 ve 48 saat sonra aynı alanlardaki yara bölgeleri alanı ImageJ (1.53e, National Institutes of Health, USA) programı kullanılarak hesaplandı. Yara iyileşmesi oranı (\%) aşağıdaki formüle göre hesaplandı.

[(yara alanı $t_{0}-$ yara alanı $\left.t\right) /$ yara alanı $\left.t_{0}\right] \times 100$

Çalışmada elde edilen veriler aritmetik ortalama \pm standart hata şeklinde verildi. İstatistik analizler, SPSS programı (PASW Statistics for Windows, version 18.0. Chicago, USA) kullanılarak yapıldı. Grupların parametrik dağılım gösterip göstermediği normalite testi ile belirlendi. Gruplar parametrik dağılım gösterdiği için OneWay ANOVA, gruplar (her grup kendi saat aralığına göre karşılaştırma yapıldı) arası farkın önemlilik kontrolü için Tukey testi (post hoc) uygulandı. Yapılan testlerde $\mathrm{P}<0,05$ değeri önemli olarak kabul edildi.

\section{Bulgular}

Tildipirosinin uygulandığı trakea epitel hücrelerine ait zamana bağlı yara iyileşme yüzdesi Tablo 1'de verildi. Buna göre $24^{\prime}$ üncü ve $48^{\prime}$ inci saatlerde, tildipirosinin yüksek konsantrasyonundan düşük konsantrasyonuna doğru in vitro sığır trakea epitel hücreleri üzerinde yapılan yaranın iyileşme yüzdesinin artığı gözlemlendi. 
Tildipirosinin $50 \mu \mathrm{g} / \mathrm{mL}^{\prime}$ lik konsantrasyonu ile kontrol grubunun, 24'üncü saatte yara alanı kapanma yüzdeleri arasında istatistiki olarak önemli fark bulunamadı $(P>0,05)$. Buna karşın 24'üncü saatte, tildipirosinin 5,10 ve $25 \mu \mathrm{g} / \mathrm{mL}^{\prime} l i k$ konsantrasyonları ile kontrol grubu arasında önemli derecede fark bulundu $(P<0,001)$. Kontrol grubuna kıyasla 25 ve $50 \mu \mathrm{mg} / \mathrm{mL}^{\prime}$ lik tildipirosin konsantrasyonları arasında $48^{\prime}$ inci saatte istatistiki olarak önemli fark bulunamadı ( $P>0,05)$. Tildipirosinin 5 ve $10 \mu \mathrm{g} / \mathrm{mL}^{\prime}$ lik konsantrasyonları ile kontrol grubunun, 48'inci saatte yara alanı kapanma yüzdeleri arasında fark anlamlı bulundu $(P<0,01)$ (Tablo 1). Tildipirosin konsantrasyonları ve kontrol grubunun, sığır trakea epitel hücresi in vitro yara ve zamana bağlı iyileşmesi görüntüleri Şekil 1'de verildi.
Tablo 1. In vitro sığır trakea epitel hücrelerinin zamana bağlı yara iyileşme yüzdesi (\%).

\begin{tabular}{lll}
\hline Konsantrasyon & 24. saat & 48. saat \\
\hline Kontrol & $56,76 \pm 2,08^{\mathrm{a}}$ & $83,33 \pm 0,33^{\mathrm{a}}$ \\
$50 \mu \mathrm{g} / \mathrm{mL}$ & $59,26 \pm 1,82^{\mathrm{a}}$ & $82,15 \pm 0,62^{\mathrm{a}}$ \\
$25 \mu \mathrm{g} / \mathrm{mL}$ & $69,02 \pm 2,45^{\mathrm{b}}$ & $86,39 \pm 2,91^{\mathrm{a}}$ \\
$10 \mu \mathrm{g} / \mathrm{mL}$ & $72,41 \pm 0,76^{\mathrm{b}}$ & $96,42 \pm 1,78^{\mathrm{b}}$ \\
$5 \mu \mathrm{g} / \mathrm{mL}$ & $74,07 \pm 0,12^{\mathrm{b}}$ & $96,61 \pm 1,69^{\mathrm{b}}$ \\
P değeri & $\mathrm{p}<0,001$ & $\mathrm{p}<0,01$
\end{tabular}

*Aynı sütundaki farklı harfleri taşıyan ortalamalar arasındaki fark anlamlıdır.

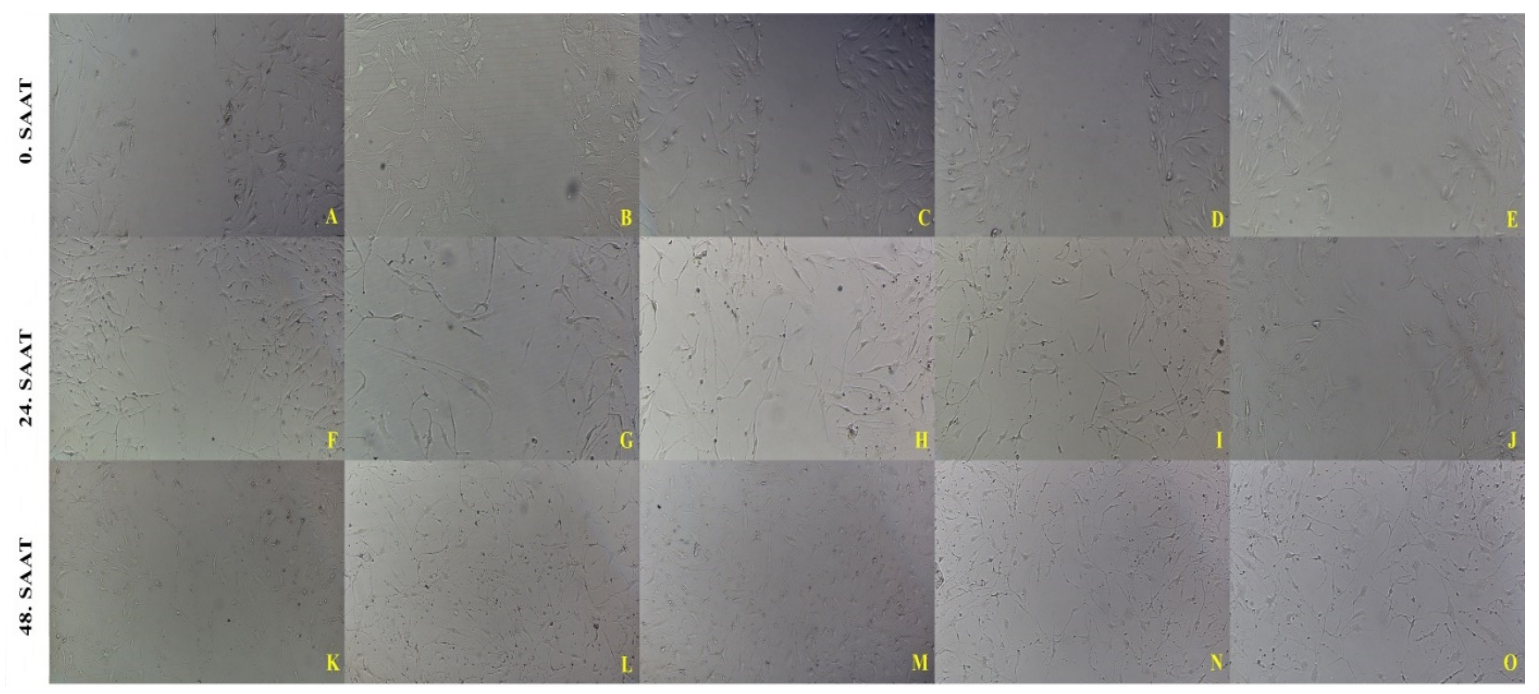

Şekil 1. Sığır trakea epitel hücresi in vitro yara ve yara iyileşmesi görüntüleri, $50 \mu \mathrm{g} / \mathrm{mL}(\mathrm{A}, \mathrm{F}, \mathrm{K}), 25 \mu \mathrm{g} / \mathrm{mL}$ (B, G, $\mathrm{L}), 10 \mu \mathrm{g} / \mathrm{mL}(\mathrm{C}, \mathrm{H}, \mathrm{M})$ ve $5 \mu \mathrm{g} / \mathrm{mL}(\mathrm{D}, \mathrm{I}, \mathrm{N})$ tildipirosin konsantrasyonları ve kontrol grubu $(\mathrm{E}, \mathrm{J}, \mathrm{O})$.

\section{Tartışma ve Sonuç}

Solunum yolu epiteli, solunum yolunun dış ortama karşı ilk savunma hattını oluşturmaktadır. Solunum yolu epitelinde meydana gelen yaralanmalardan hemen sonra, bu tabakanın bütünlüğü ve işlevlerini geri kazanması için hızla onarılması ve yenilenmesi gerekmektedir (Iosifidis ve ark., 2016). Genel olarak bu tabaka; patojeni, hücre içinde bir dizi işlemden sonrası fagolizozom aracılı öldürmeyle konak savunmasında önemli bir rol oynadığını bilinmektedir. Bazı durumlarda ise hücre içi patojenler; fagolizozom aracılı öldürmeden kaçarak, hücre içinde yerleşip ve replikasyon yapmaktadırlar. Bunun sonucu solunum yolu epiteli hasarı ve inflamatuar tepkileri tetiklemeye neden olarak, enfeksiyonun yayılmasına yol açmaktadır (Bertuzzi ve ark., 2019).
Gouzos ve ark. (2020); eritromisin, roksitromisin, azitromisin ve klaritromisin gibi antibiyotiklerin, primer insan nazal epitel hücreleri ve primer fibroblastların in vitro ortamda oluşturulan yara iyileşmesi ve reaktif oksijen türlerinin (ROS) üretimi üzerine etkilerini incelemişlerdir. Klaritromisinin; azitromisin, eritromisin ve roksitromisine göre fibroblast hücrelerinin in vitro yara iyileşme oranının daha az olduğunu bulmuşlardır. Buna karşın azitromisinin primer fibroblast ve nazal epitel hücreleri üzerinde oluşturulan yara bölgesinin $36^{\prime} \mathrm{Incl}$ saat sonunda kapandığı bildirilmiştir. Aynı çalışmada antibiyotiklerin, fibroblast ve nazal epitel hücre göçü üzerindeki etkilerinin farklılığından dolayı, postoperatif epitel iyileşmelerinin de farklı olduğu ifade edilmiştir. Sunulan çalışmada hücre hatları ve etken madde farklı olmakla birlikte tildipirosinin; Gouzos ve ark. (2020)'nın çalışmasındaki azitromisin 
gibi epitel hücre (in vitro) yara iyileşmesinde önemli etkileri bulunmaktadır. Ayrıca Gouzos ve ark. (2020) azitromisin hariç makrolid antibiyotiklerin fibroblast ve nazal epitel hücre tiplerinde ROS aktivasyonlarını azaltma eğiliminde olduğunu bildirmişlerdir. Bu ROS aktivasyonunun azalması ile hücre göçü arasında negatif ilişkinin bulunduğunu bildirilmiştir. Yapılan çalışmada tildipirosinin yüksek orandaki hücre göçü, hücre hattı farklı olmakla birlikte Gouzos ve ark. (2020)'nın çalışmasındaki makrolid antibiyotikler (azitromisin hariç) gibi ROS aktivasyonunun baskılanmasına bağıı olabileceği düşünülebilir.

Epitel dokuda yara iyileşmesi, epitel hücrelerinin koordineli göçünü ve çoğalmasını içermektedir. Yaraya bitişik epitel hücreleri, "epitel restitüsyonu" olarak da adlandırılan yara yüzeylerini örtmek için bir tabaka halinde göç etmektedir (Leoni ve ark., 2015). Mencucci ve ark. (2013) azitromisinin (\%1,5 solüsyonu) kornea epitel hücreleri üzerinde oluşturulan yarayı (in vitro) 48 'inci saat sonunda yara alanının \%47,3'ünü kapadığını ve hücrelerin yara bölgesine göç ettiğini göstermişlerdir. Yapılan çalışmada, azitromisin gibi yapısında azot grubu intiva eden tildipirosin, hücre hattı farklı olmakla birlikte Mencucci ve ark. (2013)'nın çalışması gibi düşük dozlarda 48'inci saat sonunda yara alanının yaklaşık \%90'ını kapadığını ve hücrelerin yara bölgesine göç ettiği görülmektedir. Insanlar için hazırlanmış olan azitromisin oftalmik solüsyon preparatı gibi (Mencucci ve ark., 2013), tildipirosin; solunum yolu enfeksiyonları tedavisi için geliştirilen preparatına ek olarak hayvanlar için oftalmik solüsyonu olarak da kullanılabileceği düşünülmektedir.

Sonuç olarak tildipirosinin düşük konsantrasyonlarındaki yara iyileşme yüzdelerinin (48'inci saat) yüzde yüze yakın olması, çeşitli mikroorganizma ve maddeler tarafından epitel hücrelerinde meydana gelen hasarlara karşı koruma ve tedavi etme özelliğine sahip olabilir. Sahip olduğu bu özellikle, sadece hastalık tedavisine ek olarak uzun süreli koruyucu etki de sağlayabileceği düşünülmektedir. Ayrıca ön çalışmalar yapılarak tildipirosinin, hayvanlar için oftalmik solüsyon preparatları da geliştirilebilir.

\section{Finansal destek}

Bu çalışma; Kırıkkale Üniversitesi Bilimsel Araştırma Projeleri Koordinasyon Birimi tarafından, 2020/034 proje numarası ile desteklenmiştir.

\section{Kaynaklar}

Anderson NM, Poehlsgaard J, Warrass R, Douthwaite S, 2012: Inhibition of protein synthesis on the ribosome by tildipirosin compared with other veterinary macrolides. Antimicrob Agents Chemother, 56 (11), 6033-6036.

Beckmann JD, Takizawa H, Romberger D, Illig M, Claassen L, Rickard K, Rennard SI, 1991: Serum-free culture of fracttionated bovine bronchial epithelial cells. In Vitro Cell Dev Biol, 28 (1), 39-46.

Benchaoui HA, Nowakowski M, Sherington J, Rowan TG, Sunderland SJ 2004: Pharmacokinetics and lung tissue concentrations of tulathromycin in swine. $J$ Vet Pharmacol Ther, 27 (4), 203-210.

Bertuzzi M, Hayes GE, Bignell EM, 2019: Microbial uptake by the respiratory epithelium: outcomes for host and pathogen. FEMS Microbiol Rev, 43 (2), 145-61.

Čulić O, Eraković V, Parnham MJ, 2001: Anti-inflammatory effects of macrolide antibiotics. Eur J Pharmacol, 429 (1-3), 209-229.

Fischer CD, Beatty JK, Zvaigzne CG, Morck DW, Lucas MJ, Buret AG, 2011: Anti-inflammatory benefits of antibiotic-induced neutrophil apoptosis: tulathromycin induces caspase-3-dependent neutrophil programmed cell death and inhibits NFkappaB signaling and CXCL8 transcription. Antimicrob Agents Chemother, 55 (1), 338-348.

Galecio JS, Escudero E, Cerón JJ, Crescenzo G, Marín P, 2020: Pharmacokinetics of tildipirosin in ewes after intravenous, intramuscular and subcutaneous administration. Animals (Basel), 10 (8), 1332.

Giguère S, 2013: Macrolides, azalides, and ketolides In: Antimicrobial Therapy in Veterinary Medicine, Giguére S, Prescott JF, Dowling PM (Eds), 211-231, 5th ed., Wiley Blackwell, Lowa.

Gouzos M, Ramezanpur M, Bassiouni A, Psaltis AJ, Wormald PJ, Vreugde S, 2020: Antibiotics affect ROS production and fibroblast migration in an in-vitro model of sinonasal wound healing. Front Cell Infect Microbiol, 10, 110.

Guillot L, Tabary O, Nathan N, Corvol H, Clement A, 2011: Macrolides: New therapeutic perspectives in lung diseases. Int J Biochem Cell Biol, 43 (9), 1241-1246.

lanaro A, lalenti A, Maffia P, Sautebin L, Rombola L, Carnuccio $R$, luvone $T$, D'Acquisto $F$, Di Rosa $M$, 2000: Anti-inflammatory activity of macrolide antibiotics. J Pharmacol Exp Ther, 292 (1), 156-163.

losifidis T, Garratt LW, Coombe DR, Knight DA, Stick SM, Kicic A, 2016: Airway epithelial repair in health and disease: Orchestrator or simply a player?. Respirology, 21 (3), 438-48.

Kürüm A, Karahan S, Kocamış H, Çınar M, Ergün E, 2019: Determination of antioxidants in bovine oviduct epithelial cell culture isolated at different periods of the estrous cycle. Turk J Vet Anim Sci, 43, 448-455.

Lei Z, Liu Q, Qi Y, Yang B, Khaliq H, Xiong J, Moku GK, Ahmed S, Li K, Zhang H, Zhang W, Cao J, He Q, 2018: Optimal regimens and cutoff evaluation of tildipirosin against pasteurella multocida. Front. Pharmacol, 9, 765.

Leoni G, Neumann PA, Sumagin R, Denning TL, Nusrat A, 2015: Wound repair: role of immune-epithelial interactions. Mucosal Immunol, 8 (5), 958-968.

Mencucci R, Pellegrini-Giampietro DE, Paladini L, Favuzza E, Menchini U, Scartabelli T, 2013: Azithromycin: assessment of intrinsic cytotoxic effects on corneal epithelial cell cultures. Clin Ophthalmol, 7, 965-971. 
Menge M, Rose M, Bohland C, Zschiesche E, Klip S, Metz W, Allan $M$, Röpke $R$, Nürnberger $M, 2012$ : Pharmacokinetics of tildipirosin in bovine plasma, lung tissue, and bronchial fluid (from live, nonanesthetized cattle). J Vet Pharmacol Ther, 35 (6), 550-559.

Nowakowski MA, Inskeep PB, Risk JE, Skogerboe TL, Benchaoui HA, Meinert TR, Sherington J, Sunderland SJ, 2004: Pharmacokinetics and lung tissue concentrations of tulathromycin, a new triamilide antibiotic, in cattle. Vet Ther, 5 (1), 60-74.

Papich MG, 2018: Chloramphenicaol and Derivatives, Macrolides, Lincosamides, and Miscellaneous Antimicrobials In: Veterinary Pharmacology and Therapeutics. Riviere JE, Papich MG, (eds), 903-52, 10th ed., John Wiley and Sons, Hoboken.

Peres PR, Prigol SR, Martín CBG, Feronatod C, Suriñach MC, Kreutz LC, Frandoloso R, 2020: Tildipirosin: An effective antibiotic against Glaesserella parasuis from an in vitro analysis. Vet Anim Sci, 10: 100136.

Pyörälä S, Baptiste KE, Catry B, Dujkeren EV, Greko C, Moreno MA, Pomba MCMF, Rantala M, Ružauskas $M$, Sanders P, Threlfall EJ, Torren-Edo J, Törneke K, 2014: Macrolides and lincomides in cattle and pigs: use and development of antimicrobial resistance. Vet J, 200 (2), 230-239.
Şahin Y, Yıldırım E, 2020: Antibiyotiklerin hücre içi farmakokinetik özellikleri, KÜ Tıp Fak Derg, 22 (3), 470-477.

Van Bambeke F, Barcia-Macay M, Lemaria S, Tulkens PM, 2006: Cellular pharmacodynamics and pharmacokinetics of antibiotics: Current views and perspectives. Curr Opin Drug Discov Devel, 9 (2), 218-30.

Wang X, Decker CC, Zechner L, Krstin S, wink M, 2019: In vitro wound healing of tumor cells: inhibition of cell migration by selected cytotoxic alkaloids. $B M C$ Pharmacol Toxicol, 20 (1), 4.

Zeng D, Sun M, Lin Z, Li M, Gehring R, Zeng Z, 2018: Pharmacokinetics and pharmacodynamics of tildipirosin aganist pasteurella multocida in a murine lung infection model. Front Microbiol, 9, 1038.

Zhanel GG, Dueck M, Hoban DJ, Vercaigne LM, Embil JM, Gin AS, Karlowsky JA, 2001: Review of macrolides and ketolides: focus on respiratory tract infections. Drugs, 61 (4), 443-498.

${ }^{*}$ Yazışma Adresi: Yaşar ŞAHiN

Kırıkkale Üniversitesi, Veteriner Fakültesi, Farmakoloji ve Toksikoloji Anabilim Dalı, Yahşihan, Kırıkkale, Türkiye e-mail: yasarsahin@kku.edu.tr 